\title{
Characterization and regulation of phosphatidylglycerolphosphate phosphatase in Saccharomyces cerevisiae
}

\author{
Beth L. Kelly and Miriam L. Greenberg \\ Department of Biological Chemistry and Cellular and Molecular Biology Program, University of Michigan Medical School, \\ Ann Arbor, MI (U.S.A.)
}

(Received 22 March 1990)

Key words: Phosphatidylglycerolphosphate phosphatase; Mitochondrial membrane; Phospholipid synthesis; Enzyme regulation; ( $S$. cerevisiae)

\begin{abstract}
Phosphatidylglycerophosphatase (EC 3.1.3.27) activity was characterized in mitochondrial extracts from Saccharomyces cerevisiae. The enzyme has a pH optimum of 5.5. Maximum activity occurs in the presence of Triton X-100 (5 mM) and cobalt or magnesium ions (5 mM). The apparent $K_{m}$ for PGP is $14.6 \mu \mathrm{M}$. The temperature optimum is between $50^{\circ} \mathrm{C}$ and $60^{\circ} \mathrm{C}$. The enzyme is labile above $50^{\circ} \mathrm{C}$. The presence of inositol in growth media results in a slight but reproducible increase in PGPase activity in mitochondrial extracts from glucose-grown cells but not glycerol-grown cells. The inositol effect is not seen in crude cell extracts. Carbon source does not affect PGPase activity in mitochondrial extracts or in crude cell extracts.
\end{abstract}

\section{Introduction}

The acidic phospholipid cardiolipin (CL) plays an important role in a variety of procaryotic and eucaryotic functions. In bacteria, it activates dnaA protein which is required for initiation of DNA replication [1-3]. In eucaryotic cells, $\mathrm{CL}$ is involved in at least two mitochondrial activities: it is required for cytochrome oxidase function $[4,5]$ and participates in translocation of proteins across the mitochondrial membranes [6]. In addition to its importance in mitochondrial activity, CL can serve as a marker for the study of mitochondrionspecific membrane biogenesis, since the phospholipid is found only in the mitochondrial membrane $[7,8]$.

To better understand the role of $\mathrm{CL}$ in mitochondrial function and biogenesis, we are studying the regulation of CL biosynthesis in the model eucaryote Saccharomyces cerevisiae. In eucaryotes the $\mathrm{CL}$ biosynthetic

\footnotetext{
Abbreviations: PGP, phosphatidylglycerolphosphate; PGPase, phosphatidylglycerolphosphate phosphatase; G3P, glycerol 3-phosphate; CDP-DG, CDP diacylglycerol; PG, phosphatidylglycerol; CL, cardiolipin; PGPS, PGP synthase; PA, phosphatidic acid; PI, phosphatidylinositol
}

Correspondence: M.L. Greenberg, Department Biol. Chem. and Cell Mol. Biol. Program, University of Michigan Medical School, 1301 Catherine Road, Ann Arbor, MI 48109-0606, U.S.A. pathway involves the following sequential reactions [9-12]:

(1) Glycerol 3-Phosphate (G3P) + CDP-diacylglycerol $($ CDP-DG) $\rightarrow$ Phosphatidylglycerolphosphate (PGP) + CMP

(2) $\mathrm{PGP} \rightarrow$ Phosphatidylglycerol (PG) $+\mathrm{P}_{\mathrm{i}}$

(3) $\mathrm{PG}+\mathrm{CDP}-\mathrm{DG} \rightarrow \mathrm{CL}+\mathrm{CMP}$

In bacteria the third step is $2 \mathrm{PG} \rightarrow \mathrm{CL}+$ glycerol [13]. In yeast, PGP synthase (PGPS), the enzyme that catalyzes the first reaction of the CL biosynthetic pathway, is localized in the mitochondrial inner membrane [7]. Enzymological properties of PGPS in yeast mitochondrial extracts have been described [14]. Previous work in our laboratory has shown than PGPS expression is regulated by the phospholipid precursors inositol and choline in the same manner as are enzymes of the phosphatidylinositol (PI) and phosphatidylcholine (PC) pathways [15]. However, this process is not mediated by the same genetic regulatory circuit as that controlling PI and $\mathrm{PC}$ synthesis.

PGP phosphatase (PGPase), the enzyme that catalyzes the second step of the CL pathway, has not been extensively characterized in any eucaryotic system. In Escherichia coli, two different enzymes encoded by the genes $p g p A$ and $p g p B$ carry out this reaction [16]. The pgpA gene product is specific for PGP [17], while the $p g p B$ gene product can dephosphorylate both phosphatidic acid (PA) and lysophosphatidic acid (LPA) [18]. An early biochemical analysis of PA and PGP phos- 
phatase activities in pig lung lamellar bodies, including sulfhydryl inhibition, heat inactivation, and substrate specificity studies, suggested that the same enzyme could conceivably carry out both activities [19]. However, PGPase has never been purified, nor has the gene encoding this enzyme been identified in any eucaryote.

This report is the first analysis of PGPase in the eucaryote $S$. cerevisiae. It lays the groundwork that is essential for the molecular analysis of PGPase expression. In this paper we describe the biochemical characterization of PGPase in yeast mitochondrial extracts. We show, further, that PGPase is not regulated in the same manner as PGPS, the first enzyme of the CL biosynthetic pathway.

\section{Materials and Methods}

Strains. The E. coli strain, JA200 $\left(\mathrm{F}^{+} / p g s A^{+} \Delta t r p E 5\right.$ recA thr leu thi) [20], which carries the pgsA gene on the plasmid pPGL3008 [21] was kindly provided by William Dowhan. The $S$. cerevisiae strain used was ade 5 (ade5 MAT $\alpha)[22,15]$.

Growth media. Yeast strains were maintained in $15 \%$ glycerol at $-80^{\circ} \mathrm{C}$ for long term storage and on $1 \%$ yeast extract, $2 \%$ peptone, $2 \%$ glucose (YEPD) slants at $4^{\circ} \mathrm{C}$ for short-term storage. Minimal media for experiments consisted of salts in the indicated concentrations, [ammonium sulfate $(2 \mathrm{~g} / 1)$, boric acid $(200 \mu \mathrm{g} / 1)$, copper sulfate $(16 \mu \mathrm{g} / \mathrm{l})$, potassium iodide $(40 \mu \mathrm{g} / \mathrm{l})$, ferric chloride $(80 \mu \mathrm{g} / 1)$, manganese sulfate $(160 \mu \mathrm{g} / 1)$, sodium molybdate $(80 \mu \mathrm{g} / 1)$, zinc sulfate $(160 \mu \mathrm{g} / \mathrm{l})$, potassium phosphate, monobasic $(0.4 \mathrm{~g} / \mathrm{l})$, magnesium sulfate $(0.2 \mathrm{~g} / 1)$, sodium chloride $(0.04 \mathrm{~g} / 1)$, and calcium chloride $(0.04 \mathrm{~g} / \mathrm{l})$ ], vitamins $(6), 0.15 \mathrm{mM}$ adenine, and either $2 \%$ glucose or $3 \%$ glycerol plus $0.95 \%$ ethanol. (The salts added are essentially the components of Difco vitamin-free yeast base, which also contains glucose.) Where indicated inositol was added to a concentration of $75 \mu \mathrm{M}$.

Bacterial strains were maintained in $15 \%$ glycerol at $-80^{\circ} \mathrm{C}$ for long-term storage. Media for growth of bacteria contained $5 \% \mathrm{NaCl}, 8 \%$ tryptone, $5 \%$ yeast extract and $12.5 \mu \mathrm{g} / \mathrm{ml}$ tetracycline.

Materials. All chemicals were reagent grade and were purchased from Sigma Chemical. Yeast extract, tryptone, and peptone were purchased from Difco. Other materials were purchased from the following sources: CDP-diacylglycerol (CDP-DG)-Life Sciences Resources; $\left[\gamma-{ }^{32}\right.$ P]ATP $(6000 \mathrm{Ci} / \mathrm{mmol})$-Dupont, New England Nuclear Research Products; glycerolkinaseBoehringer Mannheim; Biosafe II liquid scintillant-Research Products International; silica-gel 60 TLC platesMerck Laboratories; Whatman \#1 paper-Whatman International.
Growth conditions. For characterization of PGPase, minimal media was inoculated with yeast from YEPD slants or plates and grown overnight at $30^{\circ} \mathrm{C}$. 2-1 flasks containing 1.51 of medium were inoculated from these overnight cultures, and cells were grown to mid-log stage. Cells were harvested by centrifugation at $4^{\circ} \mathrm{C}$ and washed once with a buffer containing $50 \mathrm{mM}$ Tris- $\mathrm{HCl}$ (pH 7.5), $1 \mathrm{mM}$ EDTA, $300 \mathrm{mM}$ sucrose, and $10 \mathrm{mM}$ $\beta$-mercaptoethanol (buffer 1), and were immediately frozen at $-80^{\circ} \mathrm{C}$. To study the effects of inositol and carbon source, experimental cultures were inoculated from overnight cultures and grown to mid-log stage, to the $A_{550}$ indicated. Overnight cultures were grown in the same medium as the experimental cultures. Cells were harvested and frozen as described above.

Preparation of crude cell extracts. Extracts were prepared as described previously $[14,15]$ with the following modifications. Pellets were suspended in a buffer containing $50 \mathrm{mM}$ Tris- $\mathrm{HCl}(\mathrm{pH} \mathrm{7.5),20 \%} \mathrm{glycerol,} \mathrm{and} 10$ $\mathrm{mM} \beta$-mercaptoethanol (buffer 2) to a concentration of $1 \mathrm{~g} / \mathrm{ml}$ (wet weight), and cells were broken by vortexing with glass beads for five 1-min intervals, with cooling of the cells on ice between intervals. Extracts were centrifuged in a Sorvall SS34 rotor at $5000 \mathrm{rpm}$ for $5 \mathrm{~min}$ and supernatants were transferred to $15-\mathrm{ml}$ Corex tubes. The 5000-rpm spin was repeated twice more, each time transferring the supernatants and discarding the pellets. After the third spin, aliquots of the supernatant were saved and stored at $-80^{\circ} \mathrm{C}$.

Preparation of mitochondrial extracts. Supernatants of the last $5000-\mathrm{rpm}$ spin were transferred to small Oak Ridge tubes, and mitochondria were pelleted by centrifugation for $10 \mathrm{~min}$ at $15000 \mathrm{rpm}$ in a Sorvall SS34 rotor. Mitochondrial pellets were washed twice with buffer 2 and then stored at $-80^{\circ} \mathrm{C}$ at a final concentration of $2.5 \mathrm{mg} / \mu \mathrm{l}$ (wet weight).

Preparation of $\left[{ }^{32} P J G 3 P\right.$ and $\left[{ }^{32} P J P G P\right.$. $\left[{ }^{32} \mathrm{P}\right] \mathrm{G} 3 \mathrm{P}$ was synthesized from glycerol and $\left[\gamma^{32}\right.$ P $]$ ATP using glycerolkinase as described previously $[23,24] .\left[{ }^{32} \mathrm{P}\right] \mathrm{G} 3 \mathrm{P}$ was checked for purity by paper chromatography in 1 $\mathrm{M}$ ammonium acetate (pH 7.5) absolute ethanol (35:65), solvent system A [25]. [ ${ }^{32}$ P]PGP was synthesized as described previously [26] with the following modifications. PGPS was derived from the E. coli strain JA 200 which contains the bacterial PGPS gene on a high copy plasmid. PGPS was partially purified by the method of Gopalakrishnan et al [27]. This affinity-purified fraction was used to synthesize [ ${ }^{32}$ P]PGP under conditions described previously [26] with the exception that the incubation time was shortened from $4 \mathrm{~h}$ to $20 \mathrm{~min}$. To verify the identity of $\left[{ }^{32} \mathrm{P}\right] \mathrm{PGP}$ synthesized in this manner, the chloroform-soluble product was identified by TLC in chloroform/methanol/glacial acetic acid/water $(50: 30: 4: 8, \mathrm{v} / \mathrm{v})$ [14], subjected to mild alkaline hydrolysis [28] and the water-soluble product was chromatographed as previously described [25]. A 
single radioactive spot was detected with an $R_{\mathrm{F}}$ value corresponding to published $R_{\mathrm{F}}$ values for the alkaline hydrolysis of PGP [25].

$\left[{ }^{3} \mathrm{H}\right] \mathrm{G} 3 \mathrm{P}$ was synthesized in the same manner as $\left[{ }^{32} \mathrm{P}\right] \mathrm{G} 3 \mathrm{P}$ with the exception that $\left[{ }^{3} \mathrm{H}\right] \mathrm{glycerol}$ and unlabeled ATP were used as substrates. $\left[{ }^{3} \mathrm{H}\right] \mathrm{PGP}$ was synthesized from $\left[{ }^{3} \mathrm{H}\right] \mathrm{G} 3 \mathrm{P}$ by the same procedure described above for preparation of $\left[{ }^{32} \mathrm{P}\right] \mathrm{PGP}$.

Assays for protein and enzyme activity. Extracts were assayed for protein concentration by the method of Bradford [29] using a protein assay kit from Bio-Rad Laboratories with BSA as the standard.

PGPase activity was measured at $30^{\circ} \mathrm{C}$ for $10 \mathrm{~min}$ by following the release of water-soluble ${ }^{32} \mathrm{P}_{\mathrm{i}}$ from $100 \mu \mathrm{M}$ $\left[{ }^{32} \mathrm{P}\right] \mathrm{PGP}(20000 \mathrm{CPM} / \mathrm{nmol})$ in the presence of $5 \mathrm{mM}$ Triton X-100, $50 \mathrm{mM}$ morpholinoethanesulfonic acid$\mathrm{HCl}$, (Mes, pH 5.5), 5\% glycerol and mitochondrial extract corresponding to $1 \mu \mathrm{g}$ protein in a total volume of $0.1 \mathrm{m1}$. The reaction was stopped after $10 \mathrm{~min}$ by the addition of $0.25 \mathrm{ml} 0.1 \mathrm{M} \mathrm{HCl}$ in methanol. Chloroform $(1 \mathrm{ml})$ and $1 \mathrm{M} \mathrm{MgCl}_{2}(1.5 \mathrm{ml})$ were added. The tubes were vortexed and phases were separated by centrifugation at low speed for $3 \mathrm{~min}$. $0.75-\mathrm{ml}$ aliquots of the aqueous layer were transferred to scintillation vials, and $5 \mathrm{ml}$ Biosafe II were added to each. The amount of product formed was quantified with a Beckman LS-3801 liquid scintillation counter. Triplicate tubes were included for each sample along with a blank tube containing extract inactivated before the other reaction components were added. 1 unit of PGPase activity is defined as the amount of protein required for the release of 1 nmol ${ }^{32} \mathrm{P}_{\mathrm{i}} / \mathrm{min}$. The reaction was linear with respect to protein from 0.5 to $12 \mu \mathrm{g}$ in mitochondrial extracts and 5 to $40 \mu \mathrm{g}$ in crude cell extracts. Activity was linear with respect to time from 5 to $30 \mathrm{~min}$.

\section{Results}

\section{Optimal assay conditions}

PGPase activity was measured in citrate buffer from pH 3.0 to $\mathrm{pH} 6.0$ and Mcs buffer from $\mathrm{pH} 5.0$ to $\mathrm{pH}$ 7.0. Maximal activity was observed at pH 5.5 (Fig. 1A). Activity was measured in the presence of a variety of divalent cations (Fig. 1B). Maximal activity was obtained in the presence of cobalt or magnesium ions (5 $\mathrm{mM}$ ). Manganese did not significantly affect activity (data not shown). Zinc inhibited activity at all concentrations tested. PGPase activity was measured in the presence of various concentrations of Triton X-100 (Fig. 1C). Maximum activity occurred with $5 \mathrm{mM}$ Triton $\mathrm{X}-100$. At this concentration, the ratio of Triton X-100 to PGP is $50: 1$. At ratios greater than $50: 1$, activity decreased, indicating that the enzyme followed substrate dilution kinetics.

Enzyme activity was inhibited $100 \%$ and $70 \%$ by 1
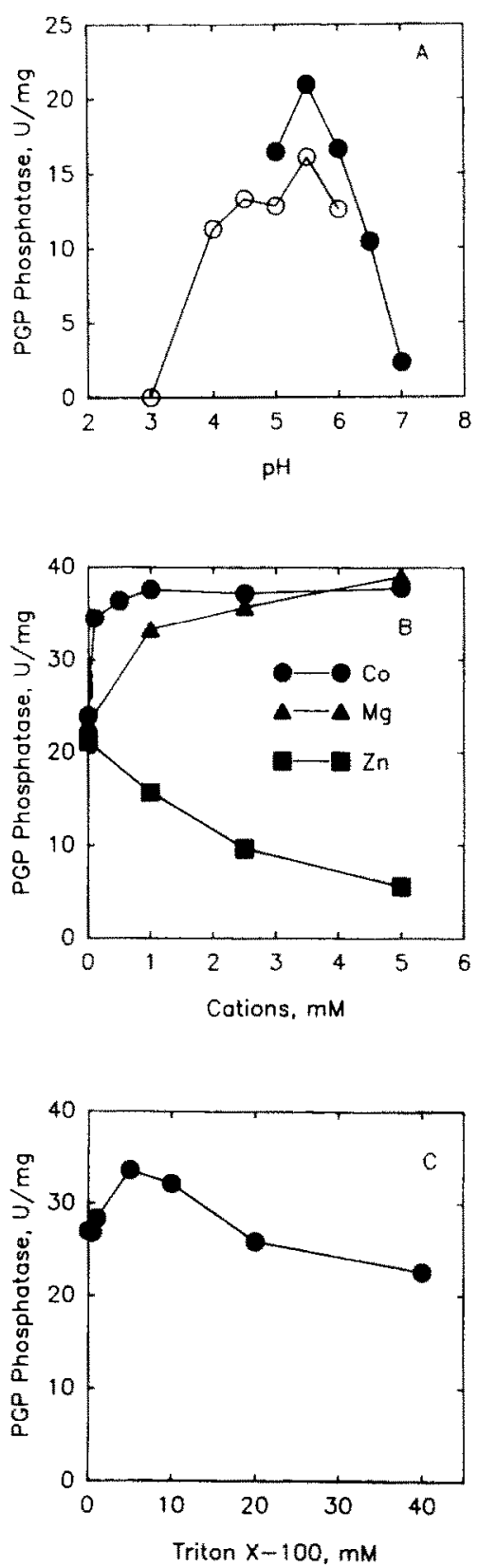

Fig. 1. Effect of $\mathrm{pH}(\mathrm{A})$, divalent cations (B) and Triton X-100 (C) on PGPase activity in mitochondrial extracts. Specific activity was determined as described in Materials and Methods. (A) Activity was measured in citrate buffer from $\mathrm{pH} 3$ to $\mathrm{pH} 6(0)$ and in Mes buffer from $\mathrm{pH} 5$ to $\mathrm{pH} 7(\bullet)$. All other conditions are the standard assay conditions described in the text. (B) Extracts were passed over a Sephadex G-25 column which had been equilibrated with buffer 2 . Samples were eluted with buffer 2 and assayed in the presence of the indicated divalent cations. All other assay conditions were standard as described in Materials and Methods. (C) Activity was measured in the presence of the indicated concentrations of Triton X-100. All other assay conditions were standard as described in Materials and Methods.

$\mathrm{mM} p$-chloromercuriphenylsulfonic acid (pCMPS) and $1 \mathrm{mM} \mathrm{NaF}$, respectively (data not shown). Inhibition by pCMPS could be reversed by $10 \mathrm{mM} \beta$-mercaptoethanol. 


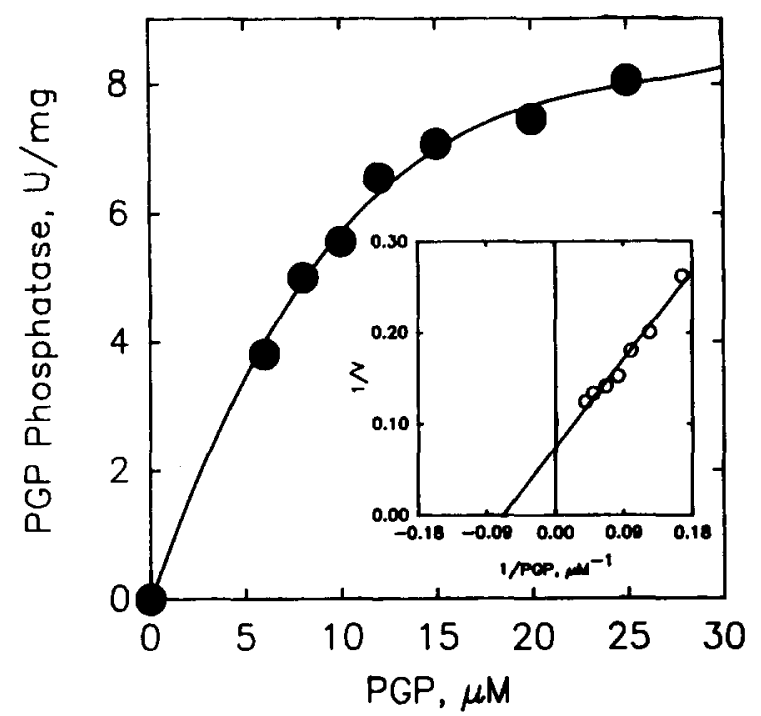

Fig. 2. Effect of PGP on PGPase activity in mitochondrial extracts. The concentration of PGP was varied while keeping the molar ratio of Triton X-100 to PGP constant at 50:1. The inset shows a double reciprocal plot of the data.

\section{Substrate affinity and specificity}

The affinity of PGPase for its substrate was determined by varying the concentration of PGP in the reaction mix. PGP was introduced to the reaction in a mixed micelle at a constant Triton X-100 to phospholipid ratio of $50: 1$. The apparent $K_{\mathrm{m}}$ for PGP was 14.6 $\mu \mathrm{M}$ (Fig. 2). Hydrolysis of PGP was not inhibited by the addition of G3P, PG, PA, or PI (data not shown).

Effect of temperature on catalysis and stability of PGPase

Enzyme activity was measured from $0^{\circ} \mathrm{C}$ to $80^{\circ} \mathrm{C}$ in a controlled temperature water bath under optimal conditions as described above. The temperature optimum for PGPase was between $50^{\circ} \mathrm{C}$ and $60^{\circ} \mathrm{C}$ (Fig. 3A). The energy of activation for the reaction was $18.3 \mathrm{kcal} / \mathrm{mol}$ between $4^{\circ} \mathrm{C}$ and $50^{\circ} \mathrm{C}$ (Fig. 3B). Stability of the enzyme to temperatures ranging from $20^{\circ} \mathrm{C}$ to $70^{\circ} \mathrm{C}$ was examined by heating extracts at the indicated temperatures for $10 \mathrm{~min}$ followed by assay under standard conditions. The enzyme was reasonably stable to temperatures up to $50^{\circ} \mathrm{C}$ with rapid inactivation at temperatures above $60^{\circ} \mathrm{C}$ (Fig. 3C).

\section{Effect of phospholipid precursors and products}

Water-soluble phospholipid precursors have been shown to affect activity of at least one phospholipid biosynthetic enzyme, phosphatidylserine synthase, which is non-competitively inhibited by inositol [30]. In contrast, water-soluble phospholipid precursors choline, ethanolamine, inositol, and serine, had no effect on PGPase activity at $1 \mathrm{mM}$ concentrations (data not shown). $P_{i}$ a product of the PGPase reaction had no effect on enzyme activity at a concentration of $1 \mathrm{mM}$ (data not shown).

\section{Identification of the reaction product}

In order to identify the phospholipid product of the reaction, the PGPase assay was carried out under standard conditions using the substrate $\left[{ }^{3} \mathrm{H}\right] \mathrm{PGP}$ (115 $\mathrm{Ci} / \mathrm{mmol}$ ). Chloroform-soluble reaction products were retained, chromatographed on TLC plates, and identi-
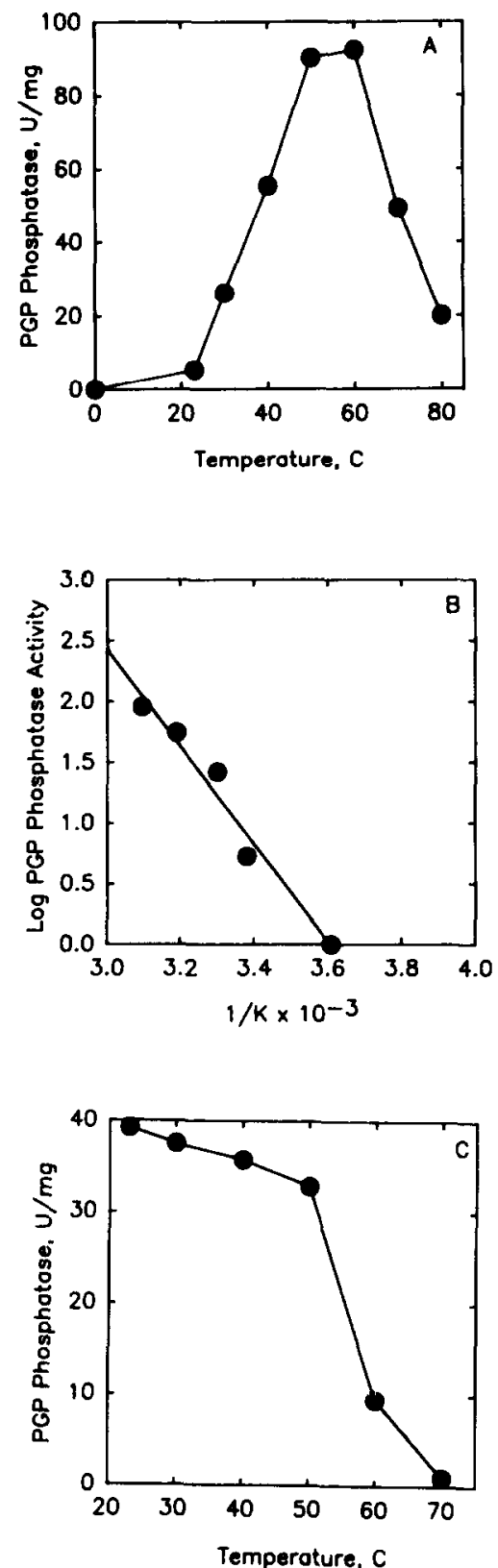

Fig. 3. Effect of temperature on PGPase activity in mitochondrial extracts. (A) Samples were incubated at the min in a controlled temperature water bath. PGPase activity was then measured under standard assay conditions as described in Materials and Methods. (B) The Arrhenius plot was constructed from the values in panel A. (C) Thermal stability of PGPase activity. Aliquots of mitochondrial extracts $(1 \mu \mathrm{g}$ protein $/ 45 \mu \mathrm{l})$ were incubated for $10 \mathrm{~min}$ at the indicated temperatures in a controlled temperature water bath. After incubation, the samples were placed on ice, assay components were added and PGPase activity was measured at $30^{\circ} \mathrm{C}$. under standard assay conditions. 
fied by exposure to X-ray film. In addition to unreacted $\left[{ }^{3} \mathrm{H}\right] \mathrm{PGP}$, a second radioactive spot was seen that comigrated with a PG standard (Fig. 4).

\section{Effect of inositol and carbon source}

We have shown previously that expression of the first cardiolipin biosynthetic enzyme, PGPS, is inhibited by growth in the presence of inositol [15]. In order to determine whether PGPase is similarly regulated, cells were grown in the presence or absence of inositol and PGPase activity was measured in mitochondrial extracts and in crude cell extracts (Fig. 5). In mitochondrial extracts of glucose-grown cells a small but reproducible derepression of PGPase activity was seen in the presence of inositol (Fig. 5B). This difference was not observed in mitochondrial extracts from cells grown in glycerol (Fig. 5B), nor was the difference detected in crude cell extracts (Fig. 5A).

We have observed that the carbon source used for cell growth affects PGPS activity (unpublished data). While activity of PGPS in mitochondrial extracts is

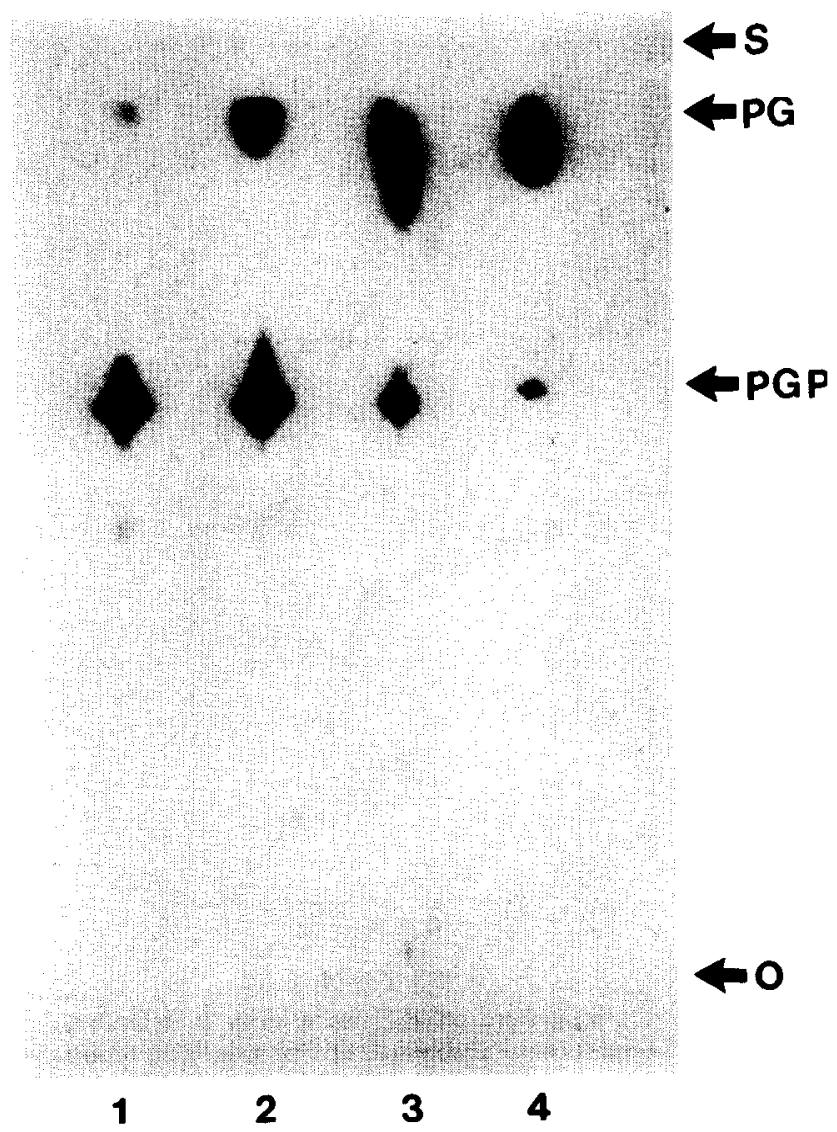

Fig. 4. Identification of the reaction products. $\left[{ }^{3} \mathrm{H}\right] \mathrm{PGP}$ was synthesized from $\left[{ }^{3} \mathrm{H}\right] \mathrm{G} 3 \mathrm{P}$ and used as the substrate in a standard PGPase assay. Chloroform-soluble products were extracted, chromatographed on a TLC plate, exposed to X-ray film and compared to unlabelled phospholipid standards. Incubation times were 0 min (lane 1), $10 \mathrm{~min}$ (lane 2), $1 \mathrm{~h}$ (lane 3), $2 \mathrm{~h}$ (lane 4). Abbreviations: S, solvent front; PG, phosphatidlyglycerol; PGP, phosphatidylglycerolphosphate; $\mathrm{O}$, origin
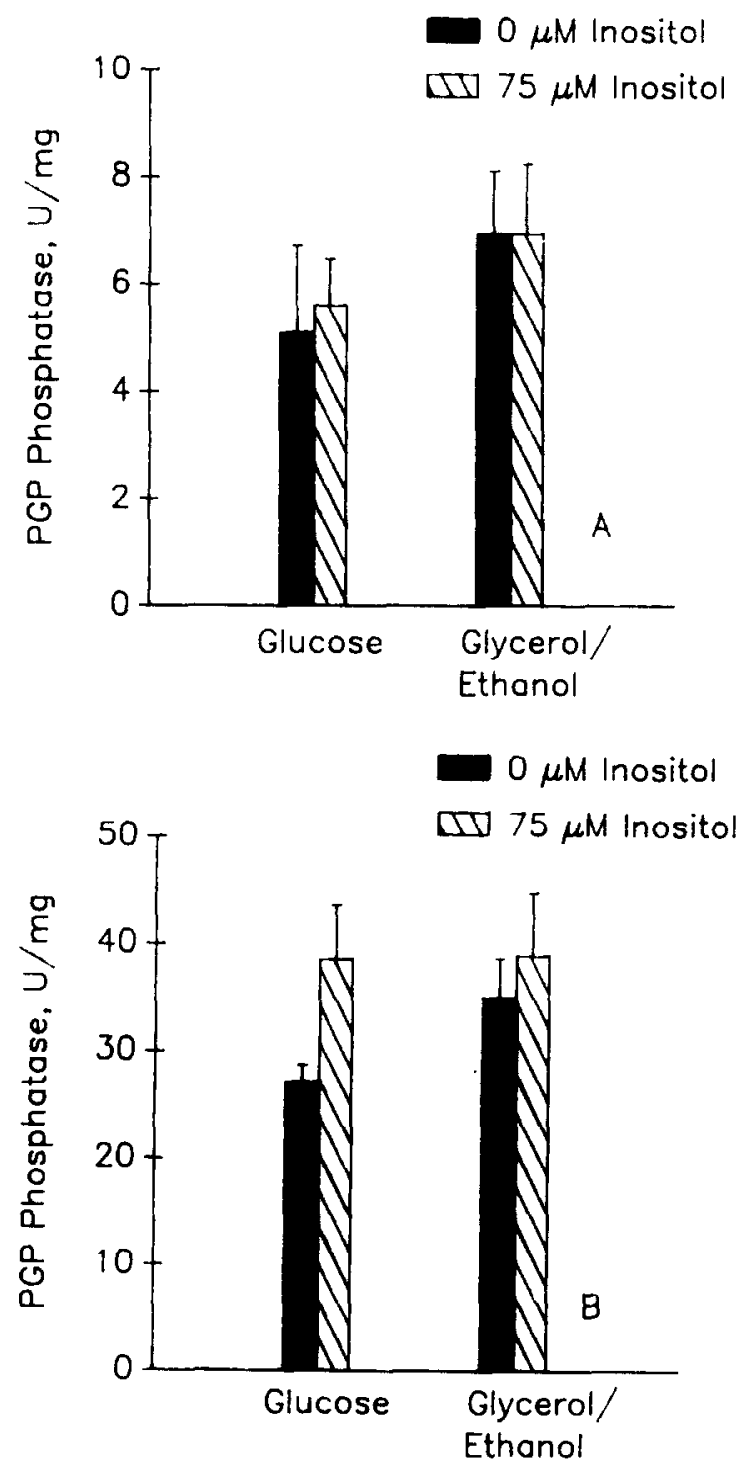

Fig. 5. Effect of inositol and carbon source on PGPase activity. Cells were grown in minimal media containing $2 \%$ glucose or $3 \%$ glycerol and $95 \%$ ethanol in the presence or absence of $75 \mathrm{UM}$ inositol. Cells were harvested at an $A_{550}$ of 0.4. Cell extracts (A) or mitochondrial extracts (B) were prepared, and PGPase activity was measured as described in the text. The specific activity of PGPase was calculated from a minimum of three independent growth studies.

similar in glucose-grown versus glycerol-grown cells, PGPS specific activity in crude cell extracts of glycerolgrown cells is 4- to 5-fold higher than in glucose-grown cell extracts (unpublished data). In contrast, the specific activity of PGPase did not vary with carbon source in mitochondrial or crude cell extracts (Fig. 5A).

\section{Discussion}

The number of enzymes which dephosphorylate phospholipid intermediates PA and PGP has not been definitively ascertained in any organism. PGPase activity has been biochemically characterized in $E$. coli [25], and subsequent genetic studies have resulted in the 
identification of two genes, and pgpA and pgpB, that encode PGPase [16]. Furthermore, evidence for a third gene is that a strain with null mutations in both pgpA and pgpB genes still has PGPase activity (William Dowhan, personal communication). In eucaryotes, PGPase has been partially characterized only in rat liver extracts [31], but the enzyme has not been purified, and the system is not readily amenable to genetic analysis. The yeast system, in contrast, lends itself to biochemical as well as genetic analysis. It is, therefore, the ideal eucaryote in which to investigate the nature of these phospholipid biosynthetic enzymes.

This is the first report describing optimal conditions for PGPase activity in the yeast $S$. cerevisiae. The yeast enzyme shares similarities and differences with both the bacterial and mammalian enzymes [26,31]. It is similar to the bacterial enzyme(s) with regard to stimulation of enzyme activity by Triton X-100 (Fig. 1C) and divalent cations (Fig. 1B). However, the yeast enzyme is not totally dependent upon these factors, while the bacterial enzyme requires divalent cations for activity [26]. The mammalian enzyme, in contrast, is inhibited by both. The yeast enzyme exhibits an apparent $K_{\mathrm{m}}$ of $14.6 \mu \mathrm{M}$ for PGP (Fig. 2), which is closer to that of the mammalian enzyme $(2 \mu \mathrm{M})$ than that reported for $E$. coli $(83$ $\mu \mathrm{M})$. The yeast PGPase temperature optimum of 50 $60^{\circ} \mathrm{C}$ (Fig. 3A) is also similar to that reported for the mammalian enzyme $\left(50^{\circ} \mathrm{C}\right)$. 'The $\mathrm{pH}$ optimum of the yeast enzyme is 5.5 (Fig. 1A) which is closer to that of the mammalian enzyme (6.3) than the bacterial enzyme (7.5).

In $E$. coli the product of the pgpB gene (but not the pgpA gene) can dephosphorylate PA as well as PGP [16-18]. In eucaryotic cells, however, characterization of the number and identity of enzymes that dephosphorylate PA and PGP is not definitive [19,31,32]. One study [19] suggests that PA and PGP phosphatase activities in rat lung are similar with regard to substrate specificities, heat inactivation, and sensitivity to sulfhydryl reagents; however, as these experiments were carried out in crude cell extracts, the number of enzymes that catalyze these reactions is uncertain. In contrast, PA phosphatase purified from yeast cell membranes is unable to dephosphorylate PGP (George Carman, personal communication). Furthermore, PA does not competitively inhibit PGP hydrolysis (data not shown). It appears therefore, that at least two different enzymes in yeast catalyze the dephosphorylation of PA and PGP.

The specific activity of PGPase that we observed in yeast mitochondrial extracts $(35 \mathrm{U} / \mathrm{mg}$ ) is 50 - to 100 fold greater than that observed for PGPS, the first enzyme in the CL pathway [15]. This may explain the fact that PGP, the product of the reaction catalyzed by PGPS, is not detected in yeast membranes [8].

PGPase appears to be regulated differently from
PGPS. We have shown previously that inositol represses expression of PGPS [15]. In contrast, PGPase activity is slightly higher in mitochondrial extracts from cells grown in glucose in the presence of inositol (Fig. 5B). A second difference between PGPS and PGPase regulation pertains to the effect of carbon source on enzyme activity. We have observed approximately 4 -fold greater PGPS activity in crude cell extracts from glycerol-grown compared to glucose-grown cells (unpublished data). PGPase activity, on the other hand, does not differ in crude cell extracts from glucose-grown versus glycerolgrown cells (Fig. 5A). While these data suggest that PGPase expression is constitutive, they may also be explained by the existence of multiple genes that encode PGPase enzymes. This report lays the groundwork for genetic and molecular studies currently in progress to identify the gene(s) encoding this enzyme.

\section{Acknowledgements}

We thank Jung Lee for assistance in preparation of the CDP-DG affinity resin, Stacey A. Minskoff for providing $\left[{ }^{3} \mathrm{H}\right] \mathrm{G} 3 \mathrm{P}$, Amiya Hajra for assistance in preparation of labeled substrates and for critically reading the manuscript, Jules Shafer for useful discussions, William Dowhan for the PGPS overproducer strain and for sharing unpublished data and Catherine A. Smith and Ruby A. Hogue for assistance in preparation of this manuscript. This work was supported by Public Health Service grant GM 37723 from the National Institutes of Health. BLK was supported in part by Public Health Service training grant T32 GM07315 from the National Institutes of Health.

\section{References}

1 Sekimizu, K. and Kornberg, A. (1988) J. Biol. Chem. 263, 71317135.

2 Sekimizu, K., Yung, B.Y. and Kornberg, A. (1988) J. Biol. Chem. 263, 7136-7140.

3 Yung, B.Y. and Kornberg, A. (1988) Proc. Natl. Acad. Sci. USA 85, 7202-7205.

4 Trivedi, A., Schwab, M., Fantin, D. and Tustanoff, E.R. (1987) in Membrane Receptors, Dynamics and Energetics (Wirtz, K.W.A. ed.), pp. 319-328, Plenum Publishing, New York.

5 Trivedi, A., Wearring, A.V., Kohlwein, S.D., Paltauf, F. and Tustanoff, E.R. (1988) in Integration of Mitochondrial Function. (Lemasters, J.J., Hackenbrock, C.R., R.G. Thurman and Weterhoff, H.V, ed.), pp. 87-94, Plenum Publishing, New York.

6 Eilers, M., Endo, T. and Schatz, G. (1989) J. Biol. Chem. 264, $2945-2950$.

7 Kuchler, K., Daum, G. and Paltauf, F. (1986) J. Bacteriol. 165, 901-910.

8 Daum, G. (1985) Biochim. Biophys. Acta 822, 1-42.

9 Cobon, G.S., Crowfoot, P.D. and Linnane, A.W. (1974) Biochem. J. 144, 265-275.

10 Moore, T.S. (1982) Annu. Rev. Plant Physiol. 33, 235-259.

11 Steiner, M.R. and Lester, R.L. (1972) Biochim. Biophys. Acta 260, 222-243. 
12 Van den Bosch, H.L., Van Golde, M.G. and Van Deenen, L.L.M., (1972) Rev. Physiol. Biochem. Exp. Pharmacol. 66, 13-145.

13 Raetz, C.R.H. (1978) Microbiol. Rev. 42, 614-659.

14 Carman, G.M. and Belunis, C.J. (1983) Can. J. Microbiol. 29, 1452-1457.

15 Greenberg, M.L., Hubbell, S. and Lam, C. (1988) Mol. Cell. Biol. 8, 4773-4779.

16 Icho, T. and Raetz, C.R.H. (1983) J. Bacteriol. 153, 722-730.

17 Icho, T. (1988) J. Bacteriol. 170, 5110-5116.

18 Icho, T. (1988) J. Bacteriol. 170, 5117-5124.

19 Johnston, J.M., Reynolds, G., Wylie, M.B, and MacDonald, P.C. (1978) Biochim. Biophys. Acta 531, 65-71.

20 Ohta, A., Waggoner, K., Radominka-Pyrek, A. and Dowhan, W. (1981) J. Bacteriol. 147, 552562.

21 Tucker, S.C., Gopalakrishnan, A.S., Bollinger, R., Dowhan, W. and Murgola, E.J. (1982) J. Bacteriol. 152, 773-779.
22 Culbertson, M.R. and Henry, S.A. (1975) Genetics. 80, 23-40. 23 Hajra, A.K. (1968) J. Biol. Chem. 243, 3458-3465.

24 Hajra, A.K. and Burke, C. (1978) J. Neurochem. 31, 125-134.

25 Chang, Y.Y. and Kennedy, E.P. (1967) J. Lipid Res. 8, 447-455.

26 Chang, Y.Y. and Kennedy, E.P. (1967) J. Lipid Res. 8, 456-462.

27 Gopalakrishnan, A.S., Chen, Y.C., Temkin. M. and Dowhan, W. (1986) J. Biol. Chem. 261, 1329-1338.

28 Larson, T.J., Hirabayashi, T. and Dowhan, W. (1976) Biochemistry. 15, 974-979.

29 Bradford, M.M. (1976) Anal. Biochem. 72, 248-254.

30 Kelly, M.J., Bailis, A.M., Henry, S.A. and Carman, G.M. (1988) J. Biol. Chem. 263, 18078-18085.

31 MacDonald, P.M. and McMurray, W.C. (1980) Biochim. Biophys. Acta 620,80-89.

32 Lipton, J.H. and McMurray, W.C. (1976) Biochem. Biophys. Res. Commun. 73, 300-305. 